Acuity 4(1),44-58

\title{
A Phenomenological Study: Speaking Anxiety Overwhelms English Learners
}

\author{
Asna Hutabarat ${ }^{1} \&$ Debora Chaterin Simanjuntak, ${ }^{2}$ \\ hutabarattina27@gmail.com ${ }^{1}$ and debora.simanjuntak@unai.edu ${ }^{2}$ \\ Universitas Advent Indonesia
}

\begin{abstract}
This study aims to determine the sources that cause speaking anxiety overwhelms English learners. It is a qualitative in nature and focuses on learners' speaking anxiety. The samples of the research are composed of senior high school students who deal with speaking anxiety. The primary data-gathering method is interview through semi-structured questions. The data were collected by in-depth face-to-face interview with 10 participants; the data were analyzed by determining the themes and description. The gathered data were analyzed using coding and verbatim quotes from research respondents.

The results show 3 themes regarding sources that cause Speaking anxiety: Limitations of English Exposure, Fear of Negative Evaluation, and Learning Condition. It is undeniable that attitude holds an imperative role in learning to speak English. The results show two themes regarding learners' attitude in causing them to become anxious whenever they speak English; the themes are selfinferiority and fear of making mistakes. Despite sources that cause learners to be anxious in speaking English, they find ways to reduce their anxiety in speaking English and from this study, there are two themes found regarding ways to reduce anxiety; they are: Media intervention and Establish learning support.
\end{abstract}

Keywords: Speaking Anxiety, Negative Evaluation, speaking skills

\section{Introduction}

English learners need four skills in learning English, namely: listening, speaking, reading, and writing skills. Among the four macro skills, speaking is the most important skill in communicating. Speaking skill is an important part of the language learning curriculum. Speaking skill plays a vital role in the communication process; Shabani (cited in El-Sakka, 2016) stated that English learners consider speaking as the most demanding skill compared to other English skills. In foreign language settings, English learners must have a proper choice of words and articulation in order for their listeners to establish good communication. Therefore, many schools in Indonesia have a curriculum that leads to the development of learner's speaking skills, with a consideration that through speaking a person will most likely be able to participate in the global movement. In the case of Indonesians, there is a high level of acceptability and tolerance of the use of English. The teaching of English in the school curriculum is given a higher priority over all other foreign languages in the school systems. Thus, the teaching of English as a Foreign Language (EFL) is in fact compulsory (Katemba, 2013). 
However, due to its importance in foreign language settings, most EFL learners encounter challenges in speaking English which lead them to have anxiety as they strive to speak the language. In Indonesia, students have difficulties in expressing themselves in the English language (Katemba \& Buli 2018). This is due to the fact that the teaching of English consists mainly of learning correct grammatical structures or forms, increasing vocabulary, working on exercises at the sentence level, and asking students to repeat similar structures over and over (Katemba,2013). The researchers revealed that English learners still face problems in speaking English. Therefore, to ensure their observation, they conducted this study to find out sources that cause anxiety in speaking English for the Indonesian learners.

The rationale of the Study

The topic of speaking anxiety has been widely investigated in the Education world especially in Indonesia. Speaking anxiety has become one of the problems that occur for most of the students when they are asked to speak in English in front of many people. Speaking anxiety has considerably existed among students even those who have good level proficiency in English. This can negatively affect on student's performance; therefore, it is necessary to investigate research on this phenomenon in order to identify the actual sources why most of the students feel anxious when they are asked to speak English. In order to carry out this analysis this study has the aim to investigate the following questions:

1. What sources that cause speaking anxiety overwhelms English-learners?

2. What is the attitude of English learners who experience speaking anxiety?

3. What are English learners' coping strategies toward speaking anxiety?

\section{Literature review}

Speaking involves two or more people who make two-way communication; it is one of the language skills in everyday life used for communication. English learners consider speaking as the most important language skill to be mastered since English is in a powerful position as a medium for international communication (Crystal, cited in Akkakoson, 2016). However, speaking in a foreign language could be influenced by psychological aspects: anxiety and self-confidence. Speaking skills has its components to be mastered by English learners. Thus, it is inevitable that components may evoke anxiety in speaking.

Component of speaking skills

There are several components of speaking skill that every English learner should be aware of. They are (1) Proper Pronunciation. Having proper pronunciation is one of the most important ways of students to produce the language. By having a good pronunciation, the students can speak in English effectively even though they have a little vocabulary. From that statement, it can be concluded that pronunciation in one of the components of speaking skill that very important for learners. Proper pronunciation is not only how people master all of the vocabularies and sounds that have isolated, on the contrary how the students to practice their English appropriately making a speaker's thought easy to follow or understand (Gilbert, 2008). (2). Grammatical utterances. 
When someone talks with others whether they can understand or not it will seem through the way of the interlocutors to construct the sentence with suitable grammar. Grammar is done by rules that can generate the sentence well-formed or grammatical utterances in the language (Purpura, 2004). Moreover, grammar refers to a set of rules to allow learners to combine the words into a sentence. (Harmer, 2001). (3) Vocabulary knowledge. Having a good knowledge of vocabulary is essential for successful speaking because without extensive vocabulary a speaker will not be able to use the structures and functions for understandable communicative. It can be said one of the keys to success in communicative, namely the power of words (Hiebert \& Kamil, 2005). (3) Speaking Fluency. Speaking fluency is defined as the ability to speak communicatively, fluently and accurately (Segalowitz, 2010). Fluency usually refers to spoken language freely without interruption. In the process of teaching and learning, if teachers want to check students' proficiency, teachers allow students to express themselves freely without interruption (Pollard, 2008). The goal is to help students speak fluently and easily. How fast and how fluent someone when speaking in English without repetition, hesitation, making a long pause, self-correction it is called fluency in speaking (Koizumi, 2005 \& Skehan, 2009).

\section{Speaking Anxiety}

Anxiety is kind of disadvantage that makes students unable to communicate well in English; in which they actually know something that has to tell but they could not show it due to anxiety (Brown, 2001). Therefore, the researcher has decided to do the research to investigate the factors that make most students feel anxious when they are asked to speak English. Eventually, the problem should be identified and studied in order to make the best lesson for everyone who wants to be a good speaker, especially in English. Many researchers noticed the phenomenon really happen in the speaking classroom. Therefore, English teachers in some of the schools in Indonesia have encouraged or made English become their target language with the aim of increasing the ability and competency in speaking English (Sundari, 2017).

Speaking anxiety is the most frequently cited concerns by the foreign language learners which may negatively affect their performance and ability to speak in the target language especially in speaking English (Mak, 2011 \& Liu, 2006). Speaking anxiety is the fear felt by the individual in the class when speaking (Zhanibek, 2001). It is consistently a significant area of interest in the language learning process because it is an important block for foreign language learning that students must overcome (Wu, 2010 \& Zheng, 2008). It prevents the productive performance of language learners while learning the target language (Hashemi \& Abbasi, 2013) and anxiety can make language learners become discouraged, lose confidence in their abilities, escape from participating in class activities, even abandon attempts to learn the language well ( $\mathrm{Na}, 2007)$ Consequently, it is important to know that speaking anxiety is a kind of fear that gives negative feelings to the learner who tries to learn language in the classroom.

Additionally, there are also a number of factors that make students feel anxious when speaking English. The causes of learning anxiety are those induced by the learner, associated with the class, related to specific abilities, and which are enforced according to different contexts. The main 
reason why anxiety occurs in learning English is the lack of belief by students about learning and has a misconception about the learning (Zhang \& Zhong, 2012). Most of the students have their own problem in speaking English, have their own reaction towards the anxiety when speaking English that influences their performance in front of the public.

\section{Methodology}

In this study, the researcher would investigate the sources on why English learners feel anxious when they speak English, the attitude of English learners in terms of speaking anxiety, and coping strategies of English learners toward speaking anxiety.

\section{Research Design}

This is a qualitative study in nature. Qualitative research is a study that intends to examine a problem or phenomenology of a subject experienced by subjects such as "behavior, perceptions, motivations and other holistic actions in a description" data descriptions derived from the experience of key informants (Sugiyono, 2006). This study utilizes the phenomenological approach; phenomenological approach deals with the understanding of how a daily, intersubjective world (the world of life). Phenomenology aims to interpret social actions in the world of social life (Heilman, 2018). This study is a direct excavation of participant experience without being affected by previous or research theory and need not test the previous assumption.

\section{Research and Setting}

In this study, the researchers involved 10 participants to provide answers to the research questions. This research used Purposive Sampling. Purposive sampling is often used in qualitative research where this method aims to identify and select key informant who is considered to provide more accurate information and are considered capable of researchers (Patton, 2002).

\section{Participants}

In the investigation of this study, the researchers involved participants from a similar family background - a family in which English is still a foreign language. To obtain a more comprehensive insider view of speaking anxiety, participants involved were expected to have, on average, English score of 60 to 70 . Moreover, the researchers deliberately involved participants from a school which is located in a rural area.

\section{Data Collection Procedures}

To answer the research questions, semi-structured interviews were utilized. The researcher made the question equal to all participants depending on the interview process and their answers but the researchers must make sure that all their answers are related in order for the researchers to collect the comprehensive data. Through the semi-structured interview, the researchers inquired about participants' feelings, anxiety, and difficulties in speaking English. This study was conducted during the school time of the academic year 2018. The questions of the interview underwent a pilot test to ensure that they comprehend the questions and also to enhance the validity of the research method. 


\section{Data Analysis Technique}

The researcher analyzed the data by utilizing the theory of Cresswell (2011). Here are the procedures to analyze the data:

a. The researcher prepared raw data for analysis.

b. The raw data were categorized based on research data, data source, and interview results.

c. The researcher read and coded all of the data, found out by paying attention to words that are often spoken by key-informants.

d. The researcher utilized the coding process and found themes or data to generate the description.

e. The researcher inter-related the theme, whether there is a relation between themes or data and interpreted the meaning of themes.

\section{Results and findings}

\section{A. Sources That Cause English Learners to Struggle from Speaking Anxiety}

After a careful analysis, sources that cause English-learners are found. They have limited outlet and time to practice their speaking skill, having a problem in using correct grammar, having a limited vocabulary and they feel difficult to pronounce the words clearly.

\section{Limitation of English Exposure}

Based on the collected data from semi-structured interviews nearly all of the participants have struggled from anxiety while speaking English. When participants were asked about their perception of sources speaking anxiety, they stated many interrelated reasons that lead keyinformants to feel anxious about speaking English. Having said this, the participants stated that they feel anxious because they have limited English exposure to practice their speaking skill. They stated that they only talk to their English-teacher and friends, and even they have limited time; wherein, they only have two (2) hours a week of English lesson. It is shown in the following excerpts of the interview:

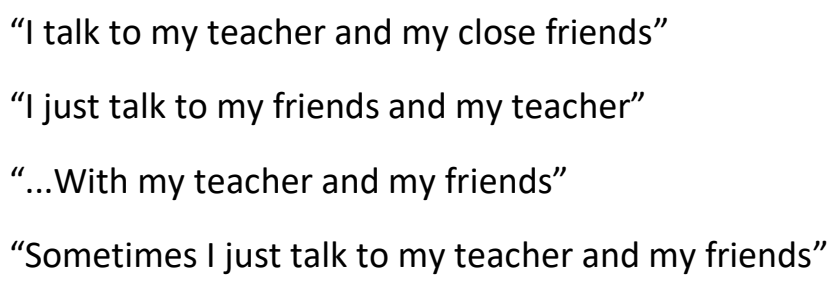

The above excerpts depicted that they mostly have few outlets to practice their speaking skills. However, to be sufficient in speaking English, learners must have a lot of exposures to practice using the language; they have to speak outside and inside the classroom effectively. Most of the participants stated the followings:

\footnotetext{
"We talk to friends and teacher only at the school"

" If we have an English class, that is the time for me to speak English"

"Only when we have English class"
} 
Whereas these key-informants mentioned that they meet their teacher and their friends only at the school, it means that they only practice their speaking skill at school. In fact, the frequency to practice persistently is very important in order to reduce anxiety (Hartanto, 2013). Having limited outlet to exposure English, apparently, it leads most of the participants to feel anxiety when they speak English. Here are the excerpts below:

"Eee,, only two hours in a week when we have English class on Monday and on Thursday"

"Two hours in a week only...on Monday and on Thursday"

"Ya, two hours in a week, if we have English class on Monday and on Thursday"

"Two hours in a week on Monday and on Thursday"

The data show that limited time is one of the sources that lead participants to feel anxious when speaking English. Meanwhile, to be a good English speaker, students must practice their speaking skill every day and practice a lot.

\section{Fear of Negative Evaluation}

Fear of negative evaluation is identified as one of the themes that lead students to feel anxious when they speak English (Horwitz, 1986; Liu \& Jackson, 2008). It is supported by the answers of participants; wherein, they had fear of negative evaluation toward speaking English. The categories emerged from this theme are difficulty in using grammar, lack of vocabulary knowledge and mispronunciation. The followings are the elaboration on each category derived from the theme:

\section{Difficulty in Using Grammar}

After making a careful analysis, the researcher found out that $80 \%$ stated that they did not know how to properly form the word to yield a correct grammar. This caused them to become anxious when speaking English in front of the class or with others. Here are the statements from the excerpts:

"I have difficulty in using grammar correctly because if I want to talk to another people, of course, I have to make it into the right sentence"

"The difficulty is in using grammar because when we want to make a sentence the grammar must be correct in order for the interlocutors understand what we are saying"

"Grammar is the difficult one, it is hard to understand the whole grammar like 16 tenses. It is needed when we want to make a sentence so that our sentence is right"

"Eeeee, Grammar, grammar is quite hard for me myself because it has a wide explanation but I cannot master it all"

Using correct grammar is challenging for the participants. Meanwhile, the use of grammar is one of the most important elements in English especially when speaking English; the speakers must have sufficient knowledge on English grammar so that their interlocutors can comprehend what the speakers are saying (Purpura, 2004). 


\section{Lack of Vocabulary Knowledge}

The fact that those participants viewed that vocabulary is one of the most important factors that make them feel anxious when they are asked to speak English in front of the class. However, this problem is a general problem for most of the students because Liu (2007) in his research, it was found that the students that he studied have the same problem in speaking that is they have limited vocabulary. About $80 \%$ of the participants defined they do not have adequate vocabulary knowledge to speak English. Therefore, in order to have good English, students should have good vocabulary knowledge in order to convey their opinions or thoughts to another person and they have to be able to choose the appropriate words (Herwanto, 2013). The followings are the statements of participants:

\footnotetext{
"Lack of vocabulary is my problem as well, because sometimes when I want to talk but I do not know how to say it in English"

"...I do not have a lot of vocabulary that is why I cannot talk a lot"

" I confused when someone talks to me, but I do not know the meaning because I do not have enough a lot of vocabulary"

"Lack of vocabulary is one of my problems in which when I want to say something, but I do not know in English, so I need to stop talking"
}

From the above excerpts, it is shown that besides using correct grammar, lack of vocabulary knowledge could lead English learners to feel anxious to speak English. Wherein the participants need to master a lot of vocabulary in order to communicate well by using the suitable and correct grammar that can be understood by many people. As Ustaci and Ok (2014) accentuated that Vocabulary is an important component of language teaching and learning process, and correct pronunciation of lexical items is an ultimate goal for English teachers or instructors who deal with English programs.

\section{Pronunciation Errors}

Pronunciation is one of the ways of the speaker to produce the language when they are talking with each other nicely. If the learners have a good utterance it will be easy for them to produce the language and to construct the words, memorize many vocabularies in the way they are practicing speaking English (Kline, 2015). However, having proper pronunciation requires hard work. Therefore participants claim that they tend to make errors in pronouncing English words. These are the excerpts from the interview:

"It is shameful for me to talk in English but I pronounce it unclear"

"Many words that I cannot pronounce it well like if there is a word using it, nd like landed, aren't ect"

"How to pronounce word by word clearly so that other people can understand what l'm saying"

"Pronunciation sometimes I do not know how to pronounce the words clearly"

The participants often times feel embarrassed when they utter unclear words. Some of them did not know how to pronounce if there is a word using "nt" or "nd" at the back of the words like landed, aren't (are not), therefore English learners ought to know the way to utter the words clearly 
so that other people easy to understand what someone is saying because some people are judging someone from the way someone pronounce the words (Ambrosino, 2014).

\section{Learning Condition}

Atmospheres of the classroom become one of the most important supports for students to learn every subject, including learning English. Comfortable, safe and conducive classroom situation will help students to enjoy learning. However, as the answer of the participants viewed that the sources that make them feel uncomfortable to learn English are that the classroom is not conducive, a disturbance was everywhere. In addition to that, a very noisy room will disturb the students' concentration in learning. The followings are the excerpts from the interview:

"The environment of the classroom is so noisy, oftentimes, I cannot concentrate on my study"

"My classroom surrounded by many students who are making noise every day. That is why I cannot study well because of them"

"We have a noisy environment, so everytime I want to study I cannot study well, my friends are laughing loudly. Actually, it's really bothering me, but I cannot say and do anything"

" My classroom surrounded by students who always making noise, oftentimes they laugh loudly, shout out loudly, sing together loudly. That makes me feel bothered when I want to study"

The classroom that is surrounded by many of disturbance, noisy lead most of the participants have no desire to study. They have a hard time focusing on what they are learning. Whereas, the classroom environment plays an important role because it contributes to students' learning output (Siddig \& Alkhoudary, 2018). In summary, the table shows sources that cause participants to feel anxious about speaking English.

Table 1. Sources that Cause Speaking Anxiety

\begin{tabular}{|c|c|c|c|c|}
\hline No & Sources & & n-10 & Percentage \\
\hline \multirow[t]{3}{*}{1} & \multirow[t]{3}{*}{ Limited outlet/time } & Friends & 7 & $70 \%$ \\
\hline & & Teachers & 9 & $90 \%$ \\
\hline & & 2 hours & 8 & $80 \%$ \\
\hline \multirow[t]{3}{*}{2} & \multirow{3}{*}{$\begin{array}{l}\text { Fear of Negative } \\
\text { Evaluation }\end{array}$} & Correct grammar & 8 & $80 \%$ \\
\hline & & $\begin{array}{l}\text { Lack of } \\
\text { vocabulary } \\
\text { Knowledge }\end{array}$ & 8 & $80 \%$ \\
\hline & & Pronounciation & 7 & $70 \%$ \\
\hline 3 & Learning condition & Unconducive class & 7 & $70 \%$ \\
\hline
\end{tabular}




\section{B. The attitude of Students to Suffer from Speaking Anxiety}

The attitude of the students toward speaking skill may play a big role in their achievement in speaking English. Farhat and Kazim (cited in Villafuerte \& Romero (2017) stated that if students possess a negative attitude, it may reduce their interest and chances to complete successful learning activities. Therefore, attitude utterly influences learners' perception of the world around them and it determines how they responded to different entities of the world. The researchers found out two themes that depict participants attitude toward speaking English. The themes are Self-inferiority and Fear of making mistake.

\section{Self-Inferiority}

Almost everyone has feeling inferior in every situation, the fact that the participants of this study feel inferior when they have to speak in front of their classmates. This is in line with what Susilawati (2017) stated, wherein, English learners tend to feel unconfident when they are asked to speak they consider themselves incapable of speaking English. They claim that they suddenly feel stressed out if they are asked to speak English. The followings are the excerpts from the interview:

"I will feel worried, stressful and nervous because I do not usually stand in front of people to speak English"

"Of course nervous, stressed out and when the teacher asks me to speak suddenly"

"Stress, nervous, especially when I do not know what to say I will feel shy because I do not know at all"

"Yaaa, stress, nervous and I immediately sweat"

These kinds of attitude have become a common problem among students such as shyness, unconfident, easily get stressed out. Often times participants feel shy, stressed out, or nervous when they are asked to speaking English in front of many people. Here are the excerpts from the interview:

"I feel not confident because it is from myself, I do not know about English, I do not know how to speak English well, my friends will laugh at me if I talk but wrong"

"I do not have knowledge about English that is why I feel shy, nervous and not confident to speak. I say something but it is wrong, I will feel shy"

"besides from my classmate and my teacher, I feel shy, not confident because I do not know what to say in front of my friends maybe they will laugh at me"

"I do not know about English, I do not know how to speak English well, it makes me feel shy and feels not confident to speak in front of my friends. $T$ is a shameful for me myself if I say something but not in the right way" 
Lack of knowledge in English is one of the reasons that make the participants feel unconfident to speak. It can be said that their anxiety comes from themselves (internal factors). Most participants feel shy and not confident because they feel that they will laugh if they make some mistakes when they speak in English.

\section{Fear of Making Mistakes}

After self-inferiority, fear of making mistakes becomes a main problem for the participants. They were very afraid of their friends' reaction regarding their performance in the class. They were mostly afraid if they were being laughed, being ridiculed by others regarding their performance, similarly that many people feel afraid to make a mistake because they worry that they will be ridiculed and considered as a strange by others (Jones, 2000). The followings are the excerpts of the interview:

"They will laugh at me and tell that I am an arrogant person because I speak in English especially when I make some mistakes in pronunciation, grammar, vocabulary"

"Of course they will laugh at me because I do not usually speak in English, I do not know how to use correct grammar and sometimes I do not know how to pronounce the words clearly, but suddenly I speak in English"

"They will laugh listen to me to speak English, usually I use Sundanese as my daily language, but suddenly I speak English, ya.. of course they will say ooo...I am an arrogant person...especially when I use wrong grammar, they will laugh at me"

"Ya...they will laugh at me, they might mock me and say something bad because people used to do it, right? Even when I use the grammar but in the right way"

From above excerpts, most things that they fear of are using proper grammar and pronouncing English words, they feel afraid of being laughed by their friends. This fact is also found in the data shows that they tend to underestimate their ability towards the language. In this sense, they are afraid of being laughed by peers due to their low ability in speaking English.

\section{Ways to reduce speaking anxiety}

In spite of many sources that impede them to speak English, they still desire to cope with their anxiety in speaking English; they make efforts to learn proper speaking. They had their own way to learn English such as media intervention, in which they use the internet as their teacher to learn English.

\section{Media Intervention}

Technology has an important role in language learning and teaching, technological advancement has open widely multiple ways to study everything for teacher especially for students. Participants of this study have considered YouTube to be very useful to improve speaking skill. YouTube is used to know varieties of English spoken around the world to provide students with authentic materials for speaking skill. The participants stated that they watch YouTube to inspire them on how to speak English. Here are some excerpts from the interview:

"I'm learning by using youtube because we can find many websites that can help me improve my speaking skill. . . like add vocabulary, learn to use grammar" 
"I'm learning English song through youtube and I can practice by following them how to construct sentences and how to pronounce the words"

"I learn by using youtube and practice more in front of the mirror, especially I learn how to pronounce the words correctly so that my friend will not get confused at me when I talk to them"

"I learn from youtube and see people in youtube how to be confident when we talk to another people, and I try to imitate them the way they pronounce the words so that we can talk like them"

The data above shows that by using youtube they can learn to speak and cope with their speaking anxiety. In addition, YouTube also helps motivate participants to study more especially in improving their speaking skill, it promotes students to be an autonomous student (Jalaluddin, 2016; Eiadeh, Sobh, Zoubi, Khasawneh, 2016). It provides an opportunity to interact with a native speaker as well as a non-native speaker of English and know a lot of different dialects and varieties of English spoken around the world. By knowing that, they could improve their speaking skill by adding vocabulary, seeing how they structure the words and grammar, the way they pronounce the words correctly. Hence, YouTube is one of the media that really help most of the students to cope with anxiety.

\section{Establish Learning Support}

Besides YouTube, learners desire to have learning support their teacher and their close friends by becoming their partners in speaking English. So that when they communicate in English, but still making mistakes, they will not laugh. The followings are the excerpts from the interview:

"Besides YouTube I learn and practice my speaking skill with my teacher and friends because if I make mistakes they will not laugh at me but they tell me the right way"

"Yaa. I should learn with my teacher and my close-friends but I talk to them face to face, and I do not feel anxious, they will teach me if I do not know."

"I'm talking with my friends for some time, and my teacher as well, because if I talk to them I will not feel anxious, and they will teach me."

The answers of key-informants show that they prefer to practice their speaking skill. The role of teacher and their friends when learning is very imperative because when making mistakes they will still support and continue to correct those mistakes, encourage them to keep studying, motivate them to not give up (Aicha, 2016).

It can be concluded that the teacher and peers play a significant role in learning speaking by students and overcoming their anxiety or obstacles by playing various roles including a facilitator or motivator. The following is table regarding the summary of participants' ways to cope up with speaking anxiety. 
Table 3. Ways to reduce speaking Anxiety

\begin{tabular}{|l|l|c|l|}
\hline No & Ways to cope up with anxiety & $\mathrm{n}=10$ & Percentage \\
\hline 1 & Media intervention (Youtube) & 9 & $90 \%$ \\
\hline 2 & Learning support (Teacher, close-friends) & 7 & $70 \%$ \\
\hline
\end{tabular}

\section{Conclusion}

Throughout this study, it has become clear that the issue of speaking anxiety considerably exists among SMAN 1 Parongpong, which may negatively affect them to enhance their speaking skill. Based on the research that has done to 10 participants, the researchers draw conclusions that there are sources that cause speaking anxiety. Anxiety comes from both internal and external sources, it depends on the situation the learners encounter when they are asked to speak English in front of their friends they got easily stressful, nervous and unconfident. On the other hand, they feel relaxed when they talk to their friends and teacher personally. Despite many obstacles or sources that impede the key-informants feel anxious to speak English, they have their own ways or efforts to improve their speaking skill such as they are using technology specifically YouTube to learn English. They can open many websites from YouTube to learn English, for instance, watching an English movie, listening to an English song.

\section{Suggestions}

This study has several suggestions for English-learners and English-teacher. Students who are learning English as their second language should be aware of their obstacles or source of anxiety in learning English (Herwanto, 2013). They also have to be aware of their feeling towards English, such as unconfident, feeling shy, get stress when speaking English.

Teachers who are teaching English as a second language hold a huge role to provoke students' interest and engage them in English subject even if they are not interested in it (Harmer, 2001). The teacher must be aware and always encourage students to learn and improve their ability. The teacher must be as a motivator and facilitator for students who are striving to speak English by knowing what they need, the background of the students, and their ability to grasp the lesson (Aicha, 2016). In addition, English-teacher should create a supportive classroom learning atmosphere in order to support them to be more excited to learn (Derakhsan, Tahery, Mirarab, 2015).

For future research, the description in the study is expected to be used as a consideration for the future researcher to conduct further research about anxiety on students' speaking English. In the next research, there should be some methods to cope with it. Various strategies need to be discovered to improve students' speaking performance (Westwick, 2014). It is important to figure out how to conduct appropriate interaction between classroom participants (key-informants). To support the effort of reducing anxiety, creating a comfortable learning classroom environment is 
also essential (Richards \& Rodgers, 2014). The next researchers should be able to identify the ideal classroom atmosphere to optimize the teaching-learning activities.

\section{References}

Aicha, B. (2016). The role of the teacher feedback in improving students speaking skill.

Akkakoson, S. (2016). Speaking Anxiety In English Conversation Classroom among Thai Students. Malaysian Journal of Learning and Instruction. (13), 63-82.

Ankunto \& Suharsimi. (2002). Metodologi Penelitian penerbit PT Rineka Cipta. Jakarta, (132).

Brown, H. D. (2001). Teaching By Principles: An Interactive Approach To Language Pedagogy. New York. Longman.

Cohen, L. Manion, L., \& Mornson, K. (2005). Research Methods in Education Fifth Edition. London. Routledge Falmer.

Cresswell, J. W. \& Plano, C. V. L. (2011). Designing and Conducting mixed method research. 2nd Sage. Thousand Oaks.

Eiadeh, A. R. Sobh, M. A., Zoubi, S. M., \& Khasawneh, F. A. (2016). Improving English Language Speaking skills of Ajloun National University Students. International Journal of English and Education. 5(3).

El-Sakka, S. M. (2016) Self-regulated Strategy Instruction for Developing Speaking Proficiency and Reducing Speaking Anxiety of Egyptian University Students. English Language Teaching. Vol. 9(12). 22-33

Hamouda, A. (2012). An Exploration of Causes of Saudi Students' Reluctance to Participate in the English Language Classroom. International Journal of English Language Education. 1(1), 1734.

Hashemi, M. \& Abbasi, M. (2013). The role of the teacher in alleviating anxiety in language classes. Int. Res. J. Appl. Basic Sci. 4(3):640- 646.

Heilman, S. (2018). A Scaffolding Approach Using Interviews and Narrative Inquiry. An online journal for teacher research. Vol. 20 (2). 1-12.

Herwanto, (2013). Factors that cause language anxiety in the classroom speaking performance in SMPN 4 Yogyakarta.

Hiebert, E. H., \& Kamil, M. L. (2005). Teaching and Learning Vocabulary. Bringing Research to Practice. Lawrence Erlbaum Associates Publishers.

Jalaluddin, M. (2016). Using YouTube to Enhance Speaking Skills in the ESL Classroom. English for Specific Purposes World. 17(50). 
Jones, J. F. (2004). A cultural context for language anxiety. EA (English Australia) J. 21(2):30-39.

Katemba, C.V. (2013), Anxiety Level of Indonesian Students and Its Relationship To Academic Achievement In English. Journal of Education and Practice Vol.4 No.27 pp. 1-9. Retrieved from http://www.iiste.org/Journals/index.php/JEP/article/view/9873/10097

Katemba, C., \& Buli, R., 2018. Improving Speaking Skills Using the Gallery Walk Technique. Catalyst, Volume 17, 2018. Retrieved from: https://apiumy.sharepoint.com/personal/sarra_apiu_edu/_layouts/15/onedrive.aspx?id=\%2Fpersonal\%2Fsarra_a piu_edu\%2FDocuments\%2FPublications\%2FCatalyst $\% 2$ F $2018 \% 2$ Fcatalyst-april2018\%2Epdf\&parent=\%2Fpersonal\%2Fsarra_apiu_edu\%2FDocuments\%2FPublications\%2FCatalys $\mathrm{t} \% 2 \mathrm{~F} 2018$

\section{https://apiu-}

my.sharepoint.com/personal/sarra_apiu_edu/_layouts/15/onedrive.aspx?id=\%2Fpersonal\%2Fsarra_a piu_edu\%2FDocuments\%2FPublications\%2FCatalyst\%2F2018\%2Faprilarticles\%2F10\%2E\%20Improving\%20Speaking\%20Skills\%20Using\%20the\%20Gallery\%20Walk\% 20Technique\%2Epdf\&parent=\%2Fpersonal\%2Fsarra_apiu_edu\%2FDocuments\%2FPublications $\% 2$ FCatalyst $\% 2$ F2018\%2Fapril-articles

Koizumi, R. (2013). Vocabulary Knowledge and Speaking Proficiency among Second Language Learners from Novice to Intermediate Levels. Academy Publisher Manufactured in Finland. $4(5)$.

Liu, M., \& Jakson, J. (2008). An Exploration of Chinese EFL Learners unwillingness to communicate and foreign language anxiety. Modern Language Journal. 92(1), 71-86.

Mak, B. (2011). An exploration of speaking-in-class anxiety with Chinese ESL learners. doi:10.1016/j.system.2011.04.002.

Marinho, F. C. A., Madeiros, D. M. A., Gama, C. C. A., \& Teixeira, C. L. (2016). Perception of College Students and Correlates. Fear of Public Speaking. Retrieved from:

Na, Z. (2007). A study of high school students" English learning anxiety. Asian EFL J. 9(3):2234.

Patton, M. Q. (2001). Qualitative Research \& Evaluation Methods third edition Sage Publications. Thousand Oaks.

Purpura, J. E. (2004). Assessing Grammar. Cambridge University Press. 24(2), 291-298. doi.org/10.1177/02655322070240020502.

Richards, J. C., \& Rodgers, T. S. (2014). Approaches and methods in language teaching (3rd ed.). Cambridge: Cambridge University Press

Segalowitz, N. (2010). The cognitive bases of second language fluency. New York, NY: 
Routledge.

Siddig, B. E. \& Alkhoudary, Y. A. (2018). Investigating Classroom Interaction: Teacher and Learner Participation. English Language Teaching. Vol. 11 (12).

Sugiono, (2006). Metode Penelitian Pendidikan. Pendekatan Kwalitatif. (3)

Skehan, P. (2009).Integrating complexity, accuracy, fluency, and lexis. Applied Linguistics. Modeling second language performance. 30(4), 510-532.

Sundari, H. (2017). Classroom Interaction in Teaching English as Foreign Language at Lower Secondary Schools in Indonesia. Advances in Language and Literary Studies. 8(6).

Togatorop, E. (2009). A Case Study at Batam Polytechnic (Doctoral dissertation, Universitas Pendidikan Indonesia). Students'obstacles In Practicing Speaking English. UNESCO Education advisory mission to Libya.

Ustaci, H. Y. \& Ok, S. (2014). Preferences of ELT Learners in the Correction of Oral Vocabulary and Pronunciation Errors. Higher Education Studies. Vol.4 (2). 29-41.

Villafuerte, J. Romero, A. (2017). Learners' Attitudes toward Foreign Language Practice on Social Network Sites. Journal of education and learning. Vol. 6 (4). 145-158.

Watson, D. \& Friend, R.(1969). Measurement of social-evaluative anxiety. Journal of consulting and clinical psychology. 33(4), 448-457.

Westwick, J. N. (2014). Overcoming Public Speaking Anxiety: Practical Applications For Classroom Instruction. The Journal of the SCASD. 1(4).

Woodrow, L. (2006). Anxiety and Speaking English as a Second Language.RELC Journal. 37(308). doi: 10.1177/0033688206071315. Retrieved from ; https://journals.sagepub.com/doi/abs/10.1177/0033688206071315

$\mathrm{Wu}, \mathrm{K}$. (2010). The relationship between language learners' anxiety and learning strategy in the CLT classrooms. Int. Educ. Stud. 3(1):174- 191.

Zhang, R. \& Zhong, J. (2012). The hindrance of doubt: Causes of language anxiety. Int. J. English Linguist. 2(3):27-33. doi:10.5539/ijel.v2n3p27.

Zhanibek, A. (2001). The relationship between language anxiety and student's participation in foreign language classes.

Zheng, Y. (2008). Anxiety and second/foreign language learning. Canadian J. New Scholars Educ. $1(1): 1-12$. 
Acuity 4(1),44-58 